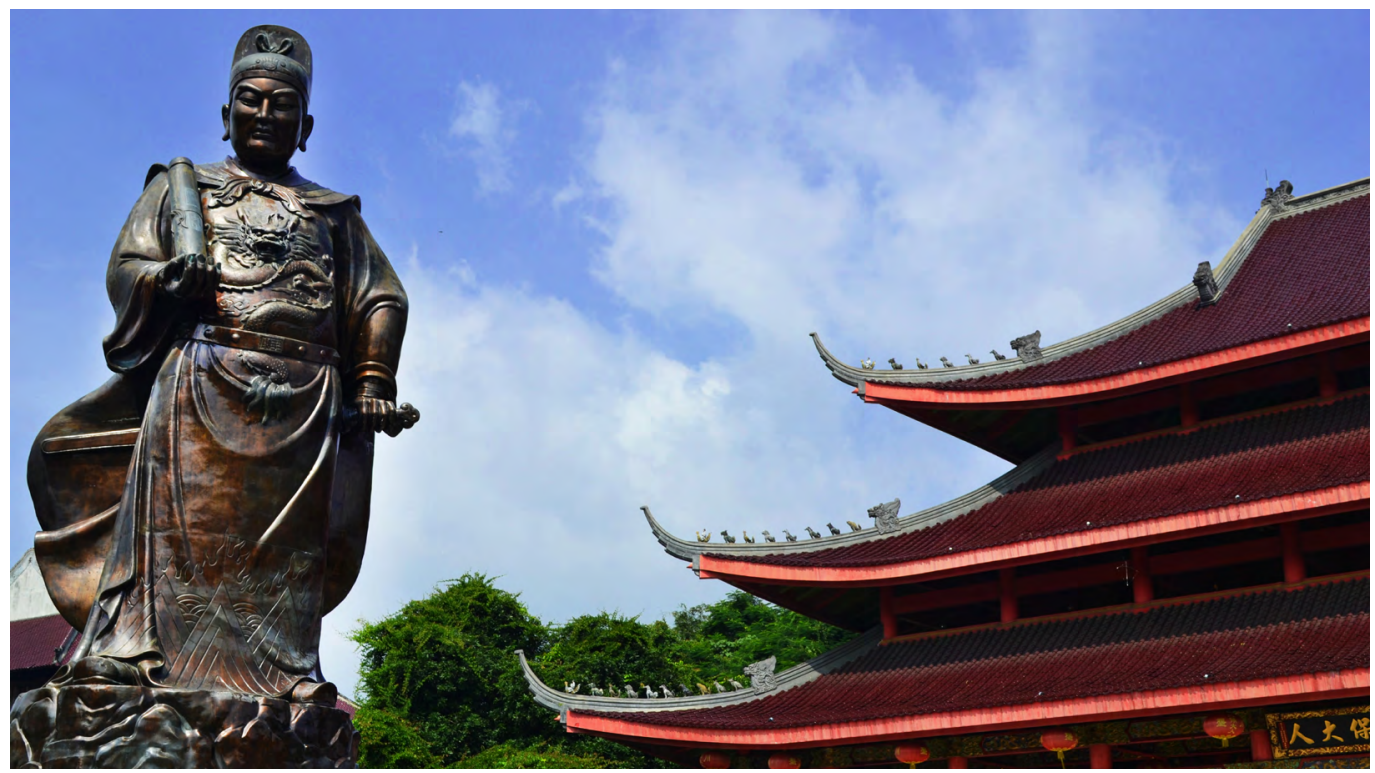

\section{The Chronopolitics \\ of the Belt and Road Initiative and Its Reinvented Histories}

\author{
Maria Adele CARRAI
}

Since the launch of the Belt and Road Initiative (BRI) in 2013, Chinese official discourse has emphasised the Initiative's continuity with the past. The reinvention of Eurasian history and heritage have become key aspects of both the promotion of the $B R I$ and China's chronopolitics. This essay examines China's political use of history and heritage in the context of the BRI, along with the related risks and geopolitical implications.
Zheng He Statue at Sam Poo Kong Temple, Java. PC: (CC) Siska Maria Eveline, Flickr.com.

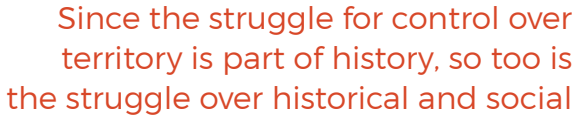

meaning.

- Edward Said, 1994

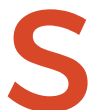
ince Chinese President Xi Jinping launched the Belt and Road Initiative (BRI, 一带一路) in 2013, discussions about it have become ubiquitous and heightened interest in Silk Road histories, archaeology, and heritage. China celebrates the ancient Silk Road and the imagined future one through conferences, exhibitions, and 
events that evoke ancient histories of connectivity and brotherhood. However, this phenomenon is not limited to China; the BRI has also become a recurring theme in heritage sites, museum exhibits, expositions, and film festivals across Eurasia, East Africa, and Southeast Asia. Countries aspiring to receive lucrative Chinese investments have promptly adopted Beijing's rhetoric claiming ancient trade and cultural ties, while adding new layers of meaning, geographies, and histories (Yang 2020).

Since the inauguration of the BRI, President Xi and other Chinese officials have used the idea of shared Eurasian history and heritage as an integral part of the metanarrative of connectivity ostensibly embodied in the BRI. In the speech he gave in 2013 at Nazarbayev University in Astana to launch the initiative, Xi described how the BRI is revitalising ancient routes:

\section{Over the past 20 years and more, the relations between China and Eurasian countries have developed rapidly, and the ancient Silk Road has gained fresh vitality. In a new way, it is taking the mutually beneficial cooperation between China and Eurasian countries to a new height. (Xi 2013)}

He also declared that the BRI reflects continuity with the past:

\section{Throughout the millennia, the people of various countries along the ancient Silk Road have jointly written a chapter of friendship that has been passed on to this very day ... This is the valuable inspiration we have drawn from the ancient Silk Road. (Xi 2013)}

The BRI, in Xi's words, has become an aspirational world of peaceful connectivity and friendship-free from all violence. It supports China's 'Great Rejuvenation' (中华民族伟大复兴) as both a world power and a great historical civilisation that can benevolently unify through 'win-win' cooperation many disparate countries and peoples under a 'community with a shared future' (人类命运共同 体) (State Council 2019). While the United States cannot rely on a multi-millennium history for its global expansion and instead looks to the futureusing 'manifest destiny' to justify its hegemonyChina is looking backwards in the new global context. It is using its imagined historical continuity and a reinvented heritage of Eurasia as an endless repertoire for whatever argument it wants to make. In particular, it wants to promote Eurasia as a place of 'solidarity, mutual trust, equality, inclusiveness, mutual learning, and win-win cooperation, [where] countries of different races, beliefs and cultural backgrounds [have been] fully capable of sharing peace and development' (Xi 2013).

China's political use of history is neither new nor unique to it (Igarashi 2000). History in different forms has always played a vital role in legitimising China's governing elites, for they saw their rule as inevitably linked to dynastic continuity. Giving the BRI historical foundations has become part of China's chronopolitics. Chronopolitics is the politics of time, and it can be understood as a discursive structure that operates within China's geopolitical narratives of the BRI. Geography is only one tool of geopolitics; the others are history and timethe former an interpretation of the latter. Chronopolitics involves simplifying time, collapsing complex historical developments into clear and neat temporal categories, figures, and analogies. History is carved up in the same way as geopolitical slices of world territory. This essay examines how political time operates in China's BRI geopolitical discourse and its chronopolitical assumptions. While China is constructing new geopolitical spaces in Eurasia and around the world, it is also remapping our understandings of time and heritage (Klinke 2013).

\section{Evoking the Ancient Silk Road}

The BRI has two major components: the Silk Road Economic Belt (丝绸之路经济带) and the Twenty-First Century Maritime Silk Road (21世纪海上 丝绸之路). However, the infrastructure policy also includes many other initiatives, such as the Digital Silk Road, the Arctic Silk Road, and the Health Silk Road. Broadly defined, the BRI is a develop- 
ment strategy promoted by the People's Republic of China according to stated goals of policy coordination and facilitating connectivity, unimpeded trade, financial integration, and people-to-people bonds (NDRC and SOA 2017). After the BRI was announced in Astana, it evolved quickly, and its official status was sealed via formal incorporation into the Chinese Communist Party's constitution in 2017 (NDRC and SOA 2017). Its roots can be found in China's Going Out Strategy (走出去战略), which was formulated by then President Jiang Zemin in the late 1990s. Existing investments and projects were then rebranded under the BRI and helped bolster Xi's image as a great rejuvenator.

Originally translated as 'One Belt, One Road', the BRI was later officially referred to as an 'initiative' (倡议), in the singular. The decision was made to emphasise how the BRI should be an open call for voluntary action in service of the public good rather than a self-interested, China-oriented plan that could imply inducement and intimidation (Xie 2015). Official Chinese documents described the $\mathrm{BRI}$ as a vision for achieving 'harmony, peace, and prosperity', not a Chinese plot to counter America's 'pivot' to Asia or a stratagem to expand Beijing's geopolitical influence worldwide (Xie 2015). The change in wording did not decrease the extent of suspicion around China's intentions. If one looks through the official documents, it becomes clear that the BRI aims primarily to benefit China (Swaine 2015). Its ultimate goal is to create a more secure environment for China's global rise. History and heritage are tools that contribute to reinforcing China's new grand narrative of Sinocentric connectivity.

The BRI, as Xi declared, revitalises the ancient Silk Road-a name that resonates with ideas about camel caravans, long-distance trade, exoticism, and describes commercial, cultural, and religious exchanges across Asia in the past. 'Silk Road' usually refers to the set of land and maritime routes that linked the West and the East in ancient times and had Rome and the ancient Chinese capital of Chang'an (today Xi'an) as ideal points of origin, but which also spread throughout Central Asia and the Middle East. However, the use of the name evokes an origin of dubious historical accuracy. The mythical title Silk Road was, in fact, coined only in 1877 by Ferdinand von Richthofen, a prominent German geographer and geologist. He used the term Seidenstraße to describe the ancient trade routes he followed during his travels. However, a Silk Road with a single origin and endpoint has never existed (Chin 2013; Tseng 2019). The notion of the Silk Road(s) is indeed arbitrary, both as a concept and as a physical geographic construct. The Silk Road was not a single great road in ancient times but rather a network of roads, rivers, and sea routes. Its many routes changed over time, and the Silk Road has since been invented and reinvented (Chin 2013; Tseng 2019).

Before the BRI was announced, other ideas for rehabilitating the Silk Road had circulated, and Xi Jinping was not the first Chinese leader to use the term. The United Nations Educational, Scientific and Cultural Organization (UNESCO) used the idea to ameliorate East-West divisions at the end of the Cold War. In 1988, the agency launched the Integral Study of the Silk Roads, the Roads of Dialogue (1988-1997) to highlight the cultural interactions between different peoples. More recently, UNESCO created the Silk Roads Online Platform for Dialogue, Diversity and Development to increase awareness of shared cultural heritage and encourage intercultural dialogue between people living along Silk Road routes (UNESCO 2017, 2021). In China, before Xi, leaders like Premier Zhou Enlai spoke about the Silk Roads and suggested reopening 'an ancient trade route ... lost to modern times, not only for trade but for strategic purposes as well' (Khalid 2009; Frankopan 2020).

These reinventions of the Silk Roads evoke an almost mythical Eurasia, comprising great civilisations interconnected by ancient routes that have supported economic, religious, cultural, and social exchanges for millennia. The BRI has also become a 'metanarrative of connectivity' that reunites the historically integrated territories of Eurasia (Winter 2021). However, there are two differences between the Silk Roads as reimagined by UNESCO and by China's BRI. First, the BRI has expanded to include states such as the Americas and different economic initiatives like the Arctic and the Digital Silk Roads. Second, and more importantly, the BRI appears to be born of China's alleged goodwill rather than emerging spontaneously from 
a plurality of countries. Through the BRI, the Chinese Government has deliberately sought to remind the world that the initiative has historical and archaeological foundations in a shared heritage of prosperous and thriving networks connecting Asia to Europe. The BRI is based on a highly stylised, romanticised vision of Eurasian history that ignores wars and imperialism. Most importantly, it creates a past in which China and its historical figures were leaders at the centre of this connectivity (Winter 2021).

\section{The Legends of Chinese History}

Given the relevance of history, it is unsurprising that certain historical figures have suddenly acquired newfound significance in China's grand BRI narrative. The Chinese imperial envoy to the outside world during the Han Dynasty, Zhang Qian (164-113 BCE); the Chinese Buddhist monk and translator who travelled by foot from ancient China to ancient India, Faxian (337-422); the Chinese Buddhist monk, scholar, traveller, and translator Xuanzang (602-64); and the Chinese admiral Zheng He (1371-1433) have all become intertwined in the new grand narrative of peaceful connectivity and brotherhood. They have become symbols of premodern cosmopolitanism and commercial, religious, and cultural exchanges. While many other historical figures have been associated with the BRI, Zhang Qian and Zheng He stand out as illustrious predecessors who introduced China to foreign peoples and established lasting bonds of mutual benefit-'win-win cooperation', in current parlance. While Zhang traversed the antecedent of the land-based route of the Silk Road, Zheng sailed the forerunner of the maritime BRI.

President Xi's 2013 speech in Astana identified Zhang Qian as the Chinese discoverer of the Silk Road. In Xi's words:

Over 2,100 years ago during China's Han Dynasty, a Chinese envoy, Zhang Qian, was sent to Central Asia twice with a mission of peace and friendship. His journeys opened the door to friendly contacts between China and Central Asian countries as well as the Silk Roads linking East and West, Asia and Europe.

In the second century $\mathrm{BC}$, the Xiongnu tribe troubled various peoples of Central Asia with continuous raids, according to official accounts. In 138 BCE, the court of Emperor Wu of the Han Dynasty sent Zhang Qian on a secret mission to western regions in search of a defensive alliance. Zhang failed, was taken prisoner, and was held by the 'barbarian' Xiongnu for more than a decade. When he later returned to his homeland, he provided the emperor with a series of descriptions of previously unknown cities and kingdoms, as well as routes and trades that already involved the empire but of which the court was not yet aware. These discoveries led to the construction of roads, trade in commodities such as silk, and exchanges between China and Central Asia (Wang 2016).

President Xi used Admiral Zheng He's heroic narrative of maritime explorations in a speech to the Indonesian Parliament to present the Twenty-First Century Maritime Silk Road. Zheng was a eunuch commander of the army at the court of Emperor Yongle of the Ming Dynasty (r. 1402-24). He was appointed admiral and led seven naval expeditions between 1405 and 1433, which earned him recognition as the greatest navigator, admiral, and Chinese ambassador. The voyages he undertook to collect tributes and find new countries with which to establish commercial relations took him to Southeast Asia, the Red Sea, and all the way to the Persian Gulf. According to the official narrative, he negotiated trade deals with African leaders on equal terms without exploiting their resources. Described as an envoy of peace and friendship, Zheng is depicted as symbolising China's openness to the world. As former Chinese state councillor Dai Bingguo (2010) said: 'Zheng He, a great Chinese navigator, led the world's strongest fleet to the Western Seas on seven voyages, taking with him not bloodshed or war, pillage or colonization but porcelain, silk and tea.' However, there is evidence that Zheng also operated as an agent of Chinese expansionism who would not hesitate to use force when countries refused to recognise China's hegemony: '[I]magine the effects upon the leaders of 
minor coastal states along Zheng's routes at the sight of an arriving fleet of two hundred immense and well-armed ships suddenly filling the horizon' (French 2017: 99-103). China's neighbours would think otherwise about Chinese claims of pacifism, and the Chinese century of humiliation corresponds to 1,000 years of Chinese domination in Vietnam. Looking at Chinese history, the scholar Victoria Tin-bor Hui (2015) notes that China was far from pacifist. There was a prevalence of civil wars and armed rebellions, and Emperor Qianlong of the Qing Dynasty (1711-99) was an expansionist. All the land included within China's sovereign borders had been incorporated through imperialist and colonial tactics (Carrai 2019).

References to Zhang Qian and Zheng He are supposed to evoke the age-old friendship and goodwill of an allegedly benign Chinese empire that cultivated equal and mutually beneficial relations with its neighbours. They testify to the solidity of the relations between China and the countries along the BRI. Xi's speech in Astana, in addition to discussing the Silk Road and Zhang Qian, cited stories of Chinese and Kazakh characters to demonstrate the friendship and trust that united both peoples (Yi 2019). Per the Chinese foreign policy playbook, such references to the Silk Road clearly function to present the BRI as an exemplification of brotherhood and shared benefits between peoples. Again, such rhetoric dismisses the complexity of history and its many conflicts; it simplifies and collapses time into mythicised temporal categories and figures.

\section{The Archaeology}

The BRI derives support from more than just sources that retell and reinvent history. More recently, the material culture of the past unearthed by state-sponsored archaeological excavations has been used to support the metanarrative of Sinocentric connectivity. Through the BRI, China has become increasingly interested in its cultural heritage. The government has collaborated with Greece, Kenya, Sri Lanka, and Tunisia to search for shipwrecks and artefacts (Zhong 2020). Findings of Chinese material culture along the ancient Silk Roads help connect the past with the present and place China at the centre of trade, connectivity, and innovation in the region-all while confirming the existence of ancient historical relations with countries along the BRI (Storozum and Yuqi 2020; Xinhua 2020). Increased Chinese investments are framed within a reconstructed history of friendship and peaceful trade that such archaeological findings purport to prove. The so-called archaeological Silk Road or Silk Road Archaeology (丝绸 之路考古) helps foster China's national rejuvenation at home and abroad, promoting the nation as an engine of connectivity, unity, and prosperity. It also contributes to restoring China's cultural prominence by developing a deep sense of historical ownership of cultural artefacts that construct national identity through collective memory (Wang 2014).

Examples of new Sino-foreign ventures include the Sino-Uzbek Mingtepa project that emphasises China's cultural and economic ties along the 'Belt' portion of the Belt and Road. Archaeological work at these sites can embed the history of the Silk Road within a narrative of progress and economic opportunity that Chinese commercialism previously helped sponsor. On Africa's Swahili Coast, there have been attempts to establish a historical and material connection with Admiral Zheng He. A team of archaeologists sent by the Chinese Ministry of Culture and the State Administration of Cultural Heritage found evidence on Kenya's coast-in collaboration with the National Museums of Kenya-of possible descendants related to Zheng's mission and ancient China-Africa ties. While these excavations provide evidence of China's presence on the Swahili Coast, forced inscriptions into the grand narrative can once again be seen as chronopolitics: an attempt to use history and its material remains in a narrative that serves to highlight China's centrality (Storozum and Yuqi 2020).

Chinese archaeological expeditions and joint ventures with foreign countries will likely increase in the coming years due to the vast resources the Chinese Government is dedicating to archaeological excavations (particularly maritime ones) and the manifold port cities in Asia and Africa that contain evidence of Chinese trade and exchange 
(Global Times 2017; Gardner 2016). Casting such material culture and archaeological findings into a reinvented history can lead indirectly to a perception of China as a 'historical driver of prosperity, peace, and political stability' (Storozum and Yuqi 2020: 284). Chinese archaeologists are actively discovering and writing their history. Still, they also seek to rewrite other countries' pasts and weave such histories into a more Sinocentric narrative (Storozum and Yuqi 2020: 285; Wang 2017). While archaeological missions are a positive development, these can also lead to the re-creation of heritage driven by Chinese foreign policy and softpower projection.

\section{The Chronopolitics of the BRI}

The BRI comprises reinvented traditions in which history, ancient figures, and archaeology serve China's chronopolitics. For Xi Jinping, the Silk Road is the 'great heritage of human civilisation', a legacy of 'peace and cooperation, openness and inclusiveness, mutual learning and mutual benefit' (Xi 2017). China portrays the BRI as an open initiative that fosters mutual benefit and a peaceful community of shared destiny. The BRI is expected to give 'fresh vitality' to the ancient routes and historical spirit based on peace and cooperation, openness and inclusivity, and mutual learning and benefit. The reinvented and reimagined ancient Silk Road symbolises the enduring strength of the Chinese civilisation and its ability to create unity. According to the official rhetoric, Zhang Qian and Zheng He were the pioneers of the Silk Roads, or the Columbuses of the East, who connected China with the world and delivered benefits to all.

The BRI perpetuates a romanticised and simplified version of Eurasian history. While the metanarrative of connectivity can help China's domestic nationalism, it is unclear whether it will be successful in boosting the idea of a 'rejuvenated' Sinocentric Eurasian civilisation abroad. Despite significant Chinese investments, other countries retain competing narratives about the Silk Road, its origins, and its geography. Still, China's histor- ical reinvention of Eurasia and the Silk Road and the casting of archaeological findings within its metanarrative of connectivity can impact on the identity processes of these countries, their paths of development, the way their museums and heritage are constructed, and the way the histories of these lands are reimagined (Murton and Lord 2020; Winter 2021). History and time are not distinct from space and geopolitics but rather integral parts of it. The chronopolitics of the BRI reinvents a history of peaceful connections and brotherhood and reorganises the rest of the world in accordance with a vision that places China at the centre. As such, China's BRI chronopolitics challenges the current geopolitical order. It calls for a more critical approach to geopolitics capable of deconstructing the chronopolitical framing and the hidden politics of time-beyond one that centres on China. 
This text is taken from Made in China Journal: Volume 6, Issue 2, 2021, edited by Ivan Franceschini and Nicholas Loubere, published 2021 by ANU Press, The Australian National University, Canberra, Australia.

doi.org/10.22459/MIC.06.02.2021.09 